GRASAS Y ACEITES 69 (1)

January-March 2018, e242

ISSN-L: 0017-3495

https://doi.org/10.3989/gya.1108172

\title{
Effect of season on the fatty acid profile of total lipids, phospholipids and triacylglycerols in Mastacembelus mastacembelus (Atatürk Dam Lake, Turkey)
}

\author{
S. Kaçar ${ }^{\mathrm{a}, ~}$, M. Başhan ${ }^{\mathrm{b}}$, S.A. Oymak ${ }^{\mathrm{c}}$ \\ ${ }^{a}$ Department of Nutrition and Dietetics, School of Health, Mardin Artuklu University, 47100 Mardin, Turkey. \\ ${ }^{b}$ Dicle University, Faculty of Science, Department of Biology, 21280 Diyarbakır, Turkey. \\ ${ }^{\mathrm{c}}$ Harran University, Faculty of Science-Literature, Department of Biology, Şanlıurfa, Turkey. \\ ${ }^{\square}$ Corresponding author: semrakacar21@gmail.com
}

Submitted: 27 October 2017; Accepted: 14 December 2017

\begin{abstract}
SUMMARY: The present study investigated the lipid content and FA profiles of total lipids, phospholipids (PL) and triacylglycerols (TAG) of Mastacembelus mastacembelus from the Atatürk Dam Lake (Turkey). The results showed that the total lipid content of the dorsal muscle varied seasonally from $0.50 \%$ to $3.59 \%$. Wide ranges of saturated fatty acids (SFAs) (36.21 to 50.52\%) and polyunsaturated fatty acids (PUFAs) $(25.22$ to $42.02 \%$ ) were found in the PL fraction. However, higher monounsaturated fatty acids (MUFAs) (37.63 to 45.07\%) and SFA (34.71 to $38.82 \%$ ) were found in TAG (triacylglycerol). The ratios of $\omega-3$ to $\omega-6$ PUFA ranged from 0.65 to 1.32 and 1.07 to 3.48 in PL (phospholipid) and TAG fraction, respectively.

The results also showed that the major components were palmitic acid (C16:0), stearic acid (C18:0), oleic acid

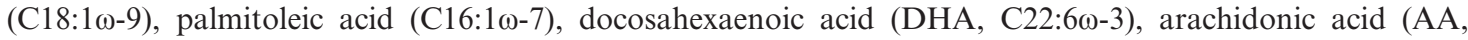

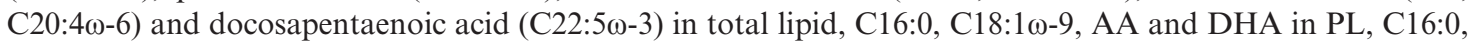

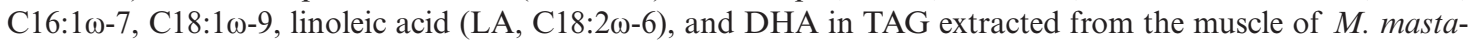
cembelus in all seasons.
\end{abstract}

KEYWORDS: Fatty acids; Gas chromatography; Mastacembelus mastacembelus; Phospholipid; Seasonal changes; Triacylglycerol

RESUMEN: Efecto estacional sobre el perfil de ácidos grasos de lípidos totales, fosfolípidos y triglicéridos de Mastacembelus mastacembelus (Lago Atatürk Dam, Turquía). En el presente estudio se investigó el contenido de lípidos y los perfiles de ácidos grasos (FA) de lípidos totales, fosfolípidos (PL) y trigliceridos (TAG) de Mastacembelus mastacembelus del lago Atatürk Dam (Turquía). Los resultados mostraron que el contenido lipídico total del músculo dorsal varió estacionalmente de $0,50 \%$ a $3,59 \%$. Se encontraron amplios rangos de ácidos grasos saturados (SFA) (36,21 a 50,52\%) y ácidos grasos poliinsaturados (PUFA) $(25,22$ a 42,02\%) en la fracción PL. Sin embargo, se encontraron ácidos grasos monoinsaturados (MUFA) más altos (37,63 a 45,07\%) y SFA $(34,71$ a $38,82 \%)$ en TAG (triacilglicerol). Las relaciones de AGPI $\omega-3$ a $\omega-6$ variaron de 0,65 a 1,32 y de 1,07 a 3,48 en PL (fosfolípido) y fracción de TAG, respectivamente. Los resultados también muestran que los principales componentes fueron ácido palmítico (C16:0), esteárico (C18:0), oleico (C18:1 $\omega-9)$, palmitoleico (C16:1 $\omega-7)$, ácido docosahexaenoico (DHA), C22:6 $\omega$-3), ácido araquidónico (AA, C20: $4 \omega-6$ ) y ácido docosapentaenoico (C22: $5 \omega-3$ ) en lípidos totales, C16:0, C18:1 $\omega-9$, AA y DHA en PL, C16:0, C16:1 $\omega-7$, C18:1 $\omega-9$, ácido linoleico (LA, C18:2 $\omega$-6) y DHA en el TAG extraído del músculo de $M$. mastacembelus en todas las estaciones.

PALABRAS CLAVE: Ácidos grasos; Cambios estacionales; Cromatografía de gases; Fosfolípido; Mastacembelus mastacembelus; Triglicéridos

ORCID ID: Kaçar S https://orcid.org/0000-0002-9869-9045, Başhan M https://orcid.org/0000-0002-1228-9548, Oymak SA https://orcid.org/0000-0002-1912-9061

Citation/Cómo citar este artículo: Kaçar S, Başhan M, Oymak SA. 2108. Effect of season on the fatty acid profile of total lipids, phospholipids and triacylglycerols in Mastacembelus mastacembelus (Atatürk Dam Lake, Turkey). Grasas Aceites 69 (1), e242. https://doi.org/10.3989/gya.1108172

Copyright: (C2018 CSIC. This is an open-access article distributed under the terms of the Creative Commons Attribution 4.0 International (CC BY 4.0) License. 


\section{INTRODUCTION}

Fish is well known for its nutritional value with essential fatty acids and its consumption is everincreasing. In particular, the $\omega-3$ FAs eicosapentaenoic acid (EPA, C20:5 $\omega-3$ ) and DHA show several properties which are beneficial to human health. $\omega-3$ FAs in fish oil have extremely beneficial and therapeutic properties for the prevention of coronary artery disease, rheumatoid arthritis, breast and colon cancer, diabetes, Alzheimer's disease, asthma, and disorders of the immune system (Sidhu, 2003). It has been proven that the consumption of fish plays a role in reducing the risk of these diseases. These findings have constituted a new market for fish oil as a food and dietary supplement to decrease the risk of attack by various illnesses. Differences in the FAs of fish not only depend on the species but also reflect the size, age, natural diet, water temperature and other environmental conditions. Spawning cycle and nutrition habits are the main factors responsible for the differences (Shirai et al., 2002).

In fish, lipids are important biochemical components which perform energy and structural functions. The lipid constituent of muscle is largely represented as the composition of total lipid content. In order to understand changes in this component it is important to study the proportional contribution of the major lipid classes, phospholipids and triacylglycerols. TAG serve mainly as a depot for fatty acids catabolized in the energy metabolism whereas PL serve as constituents of cell membranes and structures. Therefore, it is necessary to determine the FA profile of PL and TAG.

The freshwater sources of Iran and Syria were reported as the main living areas of M. mastacembelus in the first registration studies in the literature. M. mastacembelus is consumed as a food fish and is an important source of revenue for commercial fisheries in the region. M. mastacembelus is well known by local fishermen and is caught for selling, Data on the FA profiles of $M$. mastacembelus are limited. With only a few studies having been carried out on the FA profiles of this species (Harloğlu and Yılmaz, 2010; Olgunoğlu, 2011; Taşbozan et al., 2013). There is no seasonal comparison in previous studies. Besides, there has been no study on the effects of seasonal variation in the FA profiles of PL and TAG from M. mastacembelus.

In the current study, it is intended to examine the seasonal variations the FA profile of total lipids, PL and TAG in the muscles of female
M. mastacembelus from the Atatürk Dam Lake (Turkey).

\section{MATERIALS AND METHODS}

The samples of M. mastacembelus in this study were collected in Atatürk Dam Lake ( $37^{\circ} 22^{\prime} 47.07^{\prime \prime}$ North and $38^{\circ} 33^{\prime} 8.56^{\prime \prime}$ East (Bozova). The study was carried out in spring (2008), summer (2008), autumn (2008) and winter (2009).

The muscle samples for analysis were obtained from the fish body above the lateral line. Fish gender was specified by their gonads. Three female fish samples' mean length varied between 35.5 (in May) and 59.5 (in September) cm, with weights between 120 and $376 \mathrm{~g}$. The total lipid contents varied between 0.50 and 3.59 , with a typical lean-species lipid composition (Table 1). Samples were kept at $-30{ }^{\circ} \mathrm{C}$ in a freezer until they were used. Samples $(5 \mathrm{~g})$ were taken with an admixture of chloroform-methanol (2:1) using a standard method (Folch et al., 1957). The residual chloroform was then removed by $\mathrm{N}_{2}$. TAG and PL were separated into Camag twin trough chambers $(20 \times 20 \mathrm{~cm})$ previously saturated for $20 \mathrm{~min}$ with diethyl ether/petroleum ether/acetic acid (20:80:1; $\mathrm{v} / \mathrm{v})$ as the mobile phase. The mixtures of lipids were spotted onto thin layer chromatography plates (TLC, $0.25 \mathrm{~mm}$ silica gel $60 \mathrm{~F}_{254}, 20 \times 20 \mathrm{~cm}$ Merck) using a $500 \mu \mathrm{L}$ syringe. After chamber saturation the plates were developed to a distance of $16 \mathrm{~cm}$ with the development time of $40 \mathrm{~min}$. Subsequent to the development, plates were dried in a drying oven at $60^{\circ} \mathrm{C}$. Revelation of lipid fractions was carried out with 2',7'-dichlorofluorescein $(0.2 \% \mathrm{w} / \mathrm{v}$ in ethanol, obtained from Supelco), and the appropriate bands of TAG and PL fractions were visualized under a CAMAG UV cabinet (254 and $366 \mathrm{~nm}$ ). After scraping, the TAG and PL fractions were transmethylated using acidified methanol. It was refluxed for a $2 \mathrm{~h}$ at $85^{\circ} \mathrm{C}$.

Esterified samples were analyzed using a gas chromatograph (Hewlett Packard Inc, Wilmington, DE, USA) equipped with a BPX70 capillary column fused silica capillary column ( $70 \%$ cyanopropyl $30 \%$ dimethyl polysilphenylene-siloxane bonded phase, $30 \mathrm{~m} \times 0.32 \mathrm{~mm}$ (i.d.) $\times 0.250 \mu \mathrm{m}$ film thickness) and a flame-ionization detector.

Statistical analyses of data were conducted using SPSS statistics software (version 16.0) for Windows.

TABLE 1. Total lipids of the muscle of female M. mastacembelus

\begin{tabular}{lcccc}
\hline & May (2008) & July (2008) & September (2008) & January (2009) \\
\hline Total lipids of muscle (\%) & $3.59 \pm 0.03 \mathrm{a}$ & $0.77 \pm 0.02 \mathrm{~b}$ & $0.50 \pm 0.07 \mathrm{c}$ & $2.21 \pm 0.11 \mathrm{~d}$ \\
\hline
\end{tabular}

Values reported are means \pm standard deviation; means followed by different letters in same line are significantly different $(p<0.05)$. 


\section{RESULTS}

\subsection{Fat analysis}

Table 1 indicates the lipid contents of $M$. mastacembelus. The total lipid contents of tissue changed seasonally from $0.50 \%$ to $3.59 \%$. The highest lipid content of the muscle tissue was found in May (before spawning season) and the lowest content was found in September (after spawning season). In the present study, the lipid content of muscle tissue changed according to season.

\subsection{Fatty acid profile of TAG fraction}

Significant differences in the composition of some FAs were found in M. mastacembelus (Table 2).

Table 2 shows that among the SFAs detected, C16:0 is present in the highest amount.
In females, the highest SSFA amounts were found in July (during the spawning season, 38.82\%) and September (after the spawning season, 36.86\%), respectively. C16:0 content varied between $24.66 \%$ (in September) and 29.24\% (in July, during the spawning season). Other predominant SFAs were C14:0 (2.65-4.58\%) and C18:0 (3.40-5.62\%) in all seasons.

Monoenes were also high in M. mastacembelus, ranging from $37.63 \%$ (in September, after the spawning season) to $45.07 \%$ (in July, during the spawning season). The important MUFAs detected include C16:1 $\omega-7$, C18:1 $\omega-9$, eicosenoic acid (C20:1 $\omega-9)$. Among these MUFAs, C18:1 $\omega-9$ is present in the highest amount. Its highest amount was found in July (during the spawning season, $35.20 \%$ ). The lowest level was found in September (after the spawning season, $24.43 \%$ ). $\mathrm{C} 16: 1 \omega-7$ was the second most ample MUFA $(9.33-11.72 \%)$ in the present study.

TABLE 2. Seasonal variations in fatty acid composition in the triacylglycerol fraction of female M. mastacembelus $(\%$ of total FA)*

\begin{tabular}{|c|c|c|c|c|}
\hline Fatty Acids & May (2008) & July (2008) & September (2008) & January (2009) \\
\hline $\mathrm{C} 10: 0^{* *}$ & - & $0.07 \pm 0.01$ & $0.28 \pm 0.04$ & - \\
\hline $\mathrm{C} 12: 0$ & - & $0.08 \pm 0.02$ & $0.44 \pm 0.08$ & - \\
\hline C13:0 & - & $0.29 \pm 0.02$ & $0.20 \pm 0.07$ & - \\
\hline $\mathrm{C} 14: 0$ & $4.15 \pm 0.98^{\mathrm{a}}$ & $2.83 \pm 0.87^{\mathrm{b}}$ & $4.58 \pm 0.23^{\mathrm{a}}$ & $2.65 \pm 0.14^{\mathrm{b}}$ \\
\hline $\mathrm{C} 15: 0$ & $0.84 \pm 0.14^{\mathrm{a}}$ & $0.47 \pm 0.01^{\mathrm{b}}$ & $1.74 \pm 0.28^{\mathrm{c}}$ & $0.91 \pm 0.02^{\mathrm{a}}$ \\
\hline C16:0 & $25.11 \pm 1.21^{\mathrm{a}}$ & $29.24 \pm 1.86^{\mathrm{b}}$ & $24.66 \pm 1.45^{\mathrm{a}}$ & $27.38 \pm 1.20^{\mathrm{b}}$ \\
\hline $\mathrm{C} 17: 0$ & $0.67 \pm 0.04^{\mathrm{a}}$ & $0.22 \pm 0.06^{\mathrm{b}}$ & $1.04 \pm 0.07^{\mathrm{c}}$ & $1.20 \pm 0.08^{\mathrm{c}}$ \\
\hline C18:0 & $3.94 \pm 0.77^{\mathrm{a}}$ & $5.62 \pm 0.56^{\mathrm{b}}$ & $3.92 \pm 0.34^{\mathrm{a}}$ & $3.40 \pm 0.95^{\mathrm{a}}$ \\
\hline $\operatorname{ESFA}^{* * *}$ & $34.71 \pm 2.21^{\mathrm{a}}$ & $38.82 \pm 1.90^{\mathrm{a}}$ & $36.86 \pm 1.87^{\mathrm{a}}$ & $\mathbf{3 5 . 5 4} \pm 1.65^{\mathrm{a}}$ \\
\hline $\mathrm{C} 16: 1 \omega-7$ & $11.72 \pm 1.11^{\mathrm{a}}$ & $9.33 \pm 1.08^{\mathrm{a}}$ & $11.57 \pm 1.05^{\mathrm{a}}$ & $10.71 \pm 1.00^{\mathrm{a}}$ \\
\hline C18:1 $\omega-9$ & $30.62 \pm 1.20^{\mathrm{a}}$ & $35.20 \pm 1.89^{\mathrm{b}}$ & $24.43 \pm 1.27^{\mathrm{c}}$ & $29.62 \pm 1.85^{\mathrm{a}}$ \\
\hline $\mathrm{C} 20: 1 \omega-9$ & $1.39 \pm 0.75^{\mathrm{a}}$ & $0.54 \pm 0.04^{\mathrm{b}}$ & $1.63 \pm 0.45^{\mathrm{a}}$ & $0.47 \pm 0.08^{\mathrm{b}}$ \\
\hline EMUFA $^{* * *}$ & $43.73 \pm 2.20^{\mathrm{a}}$ & $45.07 \pm 2.31^{\mathrm{a}}$ & $37.63 \pm 1.98^{b}$ & $40.80 \pm 2.28^{a}$ \\
\hline $\mathrm{C} 18: 2 \omega-6$ & $3.97 \pm 0.54^{\mathrm{a}}$ & $6.34 \pm 0.87^{\mathrm{b}}$ & $2.18 \pm 0.45^{\mathrm{c}}$ & $5.49 \pm 0.90^{\mathrm{b}}$ \\
\hline $\mathrm{C} 18: 3 \omega-3$ & $2.12 \pm 0.02^{\mathrm{a}}$ & $0.70 \pm 0.01^{\mathrm{b}}$ & $0.96 \pm 0.42^{\mathrm{b}}$ & $4.01 \pm 0.23^{\mathrm{c}}$ \\
\hline $\mathrm{C} 20: 2 \omega-6$ & $0.39 \pm 0.07^{\mathrm{a}}$ & $0.12 \pm 0.03^{\mathrm{b}}$ & $0.30 \pm 0.04^{\mathrm{a}}$ & $0.38 \pm 0.01^{\mathrm{a}}$ \\
\hline $\mathrm{C} 20: 3 \omega-6$ & $0.39 \pm 0.04^{\mathrm{a}}$ & $0.53 \pm 0.09^{\mathrm{b}}$ & $0.21 \pm 0.02^{\mathrm{c}}$ & $0.69 \pm 0.34^{\mathrm{b}}$ \\
\hline $\mathrm{C} 20: 4 \omega-6$ & $2.31 \pm 0.47^{\mathrm{a}}$ & $0.70 \pm 0.08^{\mathrm{b}}$ & $2.92 \pm 0.01^{\mathrm{a}}$ & $3.34 \pm 0.56^{\mathrm{c}}$ \\
\hline $\mathrm{C} 20: 5 \omega-3$ & $2.21 \pm 0.34^{\mathrm{a}}$ & $0.43 \pm 0.15^{\mathrm{b}}$ & $1.72 \pm 0.44^{\mathrm{a}}$ & $1.01 \pm 0.03^{\mathrm{c}}$ \\
\hline $\mathrm{C} 22: 5 \omega-3$ & $3.29 \pm 0.67^{\mathrm{a}}$ & $1.64 \pm 0.56^{\mathrm{b}}$ & $7.43 \pm 0.40^{c}$ & $3.45 \pm 0.77^{\mathrm{a}}$ \\
\hline$C 22: 6 \omega-3$ & $6.76 \pm 0.41^{\mathrm{a}}$ & $5.48 \pm 0.06^{\mathrm{a}}$ & $9.46 \pm 0.98^{b}$ & $5.21 \pm 0.44^{\mathrm{a}}$ \\
\hline EPUFA $^{* * *}$ & $21.26 \pm 1.05^{\mathrm{a}}$ & $\mathbf{1 5 . 9 4} \pm 1.66^{\mathrm{b}}$ & $25.18 \pm 1.99^{\mathrm{a}}$ & $23.58 \pm 1.09^{\mathrm{a}}$ \\
\hline$\sum \omega-3$ & 14.38 & 8.25 & 19.57 & 13.68 \\
\hline$\sum \omega-6$ & 6.88 & 7.69 & 5.61 & 9.90 \\
\hline$\omega-3 / \omega-6$ & 2.09 & 1.07 & 3.48 & 1.38 \\
\hline
\end{tabular}

* Means are the average of 3 replicates.

** Values are provided as mean \pm S.D. Significant difference at a level of $P<0.05$ is designated by 'a', 'b', 'c', and 'd' (Tukey's test); the same letters in different periods indicate no significant difference.

*** SFA: saturated fatty acids, MUFA: monounsaturated fatty acids, PUFA: polyunsaturated fatty acids. 
However, the decrease in the proportion of $\mathrm{C} 16: 1$ $\omega-7$ of M. mastacembelus in July was not statistically significant $(\mathrm{p}<0.05)$.

Among the polyunsaturated $\omega-3$ and $\omega-6$ FAs C18:2 $\omega-6$, linolenic acid (ALA, C18:3 $\omega-3$ ), eicosadienoic acid (C20:2 $\omega-6)$, eicosatrienoic acid (C20:3 $\omega-6)$, AA, EPA, C22:5 $\omega-3$, and DHA are worth mentioning. Throughout the year, PUFAs accounted for $15.94-25.18 \%$ of the TAG FA profile. Total PUFA was considerably higher in autumn than in summer. DHA was the predominant PUFA for all seasons. DHA in the muscle tissue of M. mastacembelus was determined to be $5.21 \%, 5.48 \%, 6.76 \%$ and $9.46 \%$ in January, July, May and September, respectively. With regards to PUFA, the levels of total $\omega-3$ ones were lower than those of $\omega-6$ ones.

However, long carbon chain PUFAs like C20:2 $\omega-6, C 20: 3 \omega-6$ were found negligible in M. mastacembelus.
It was detected that the relative proportions of PUFA, $\omega-3$ and $\omega-6$ FAs were reduced to a minimum in July (8.25\%) and September (5.61\%), respectively. It was found that the $\omega-3$ FA level increased in September (19.57\%). The highest $\omega-3 / \omega-6$ ratios of TAGs were recorded in September (3.48).

\subsection{Fatty acid profile of PL fraction}

The percentage compositions of the various FAs in the M. mastacembelusis given in Tables 3 .

The results also show that the percentage of FAs differed amongst seasons in female fish species, varying from $36.21 \%$ to $50.52 \%$ SFAs; $17.89 \%$ to $24.11 \%$ MUFAs, and $25.22 \%$ to $42.02 \%$ PUFAs. Among those studied, C16:0 was a major SFA while C18:0 was the other major constituent. Unsaturated monoenoic FAs e.g. C18:1 $\omega-9$ and C16:1 $\omega-7$, were the major constituents and dienoic

TABLE 3. Seasonal variations in fatty acid composition in the phospholipid fraction of female M. mastacembelus $(\%$ of total FA)*

\begin{tabular}{|c|c|c|c|c|}
\hline Fatty Acids & May (2008) & July (2008) & September (2008) & January (2009) \\
\hline $\mathrm{C} 10: 0^{* *}$ & $0.08 \pm 0.03$ & - & - & - \\
\hline $\mathrm{C} 12: 0$ & $0.06 \pm 0.02$ & - & - & - \\
\hline C13:0 & $0.14 \pm 0.02$ & $0.79 \pm 0.04$ & - & - \\
\hline $\mathrm{C} 14: 0$ & $1.94 \pm 0.88^{\mathrm{a}}$ & $1.81 \pm 0.76^{\mathrm{a}}$ & $1.05 \pm 0.06^{\mathrm{b}}$ & $0.77 \pm 0.56^{\mathrm{b}}$ \\
\hline C15:0 & $0.73 \pm 0.23^{\mathrm{a}}$ & $0.77 \pm 0.13^{\mathrm{a}}$ & $0.75 \pm 0.04^{\mathrm{a}}$ & $0.42 \pm 0.16^{\mathrm{b}}$ \\
\hline C16:0 & $34.32 \pm 1.21^{\mathrm{a}}$ & $36.19 \pm 1.20^{\mathrm{a}}$ & $34.15 \pm 1.67^{\mathrm{a}}$ & $27.36 \pm 1.44^{\mathrm{b}}$ \\
\hline $\mathrm{C} 17: 0$ & $0.29 \pm 0.09^{\mathrm{a}}$ & $1.70 \pm 0.30^{\mathrm{b}}$ & $0.33 \pm 0.08^{\mathrm{a}}$ & $0.98 \pm 0.13^{\mathrm{c}}$ \\
\hline C18:0 & $9.55 \pm 0.10^{\mathrm{a}}$ & $9.26 \pm 0.30^{\mathrm{a}}$ & $10.17 \pm 0.99^{\mathrm{a}}$ & $6.68 \pm 0.45^{\mathrm{b}}$ \\
\hline ESFA $^{* * *}$ & $47.11 \pm 2.65^{\mathrm{a}}$ & $\mathbf{5 0 . 5 2} \pm 2.98^{\mathrm{a}}$ & $46.45 \pm 1.90^{\mathrm{a}}$ & $36.21 \pm 1.45^{\mathrm{b}}$ \\
\hline$C 16: 1 \omega-7$ & $3.01 \pm 0.06^{\mathrm{a}}$ & $2.34 \pm 0.33^{\mathrm{a}}$ & $2.47 \pm 0.11^{\mathrm{a}}$ & $2.66 \pm 0.95^{\mathrm{a}}$ \\
\hline C18:1 $\omega-9$ & $17.6 \pm 0.99^{\mathrm{a}}$ & $20.9 \pm 1.05^{\mathrm{b}}$ & $15.42 \pm 1.44^{\mathrm{a}}$ & $18.09 \pm 1.00^{\mathrm{a}}$ \\
\hline C20:1 $\omega-9$ & $0.74 \pm 0.34^{\mathrm{a}}$ & $0.87 \pm 0.23^{\mathrm{a}}$ & - & $0.92 \pm 0.09^{\mathrm{a}}$ \\
\hline EMUFA $^{* * *}$ & $21.35 \pm 1.26^{\mathrm{a}}$ & $24.11 \pm 1.87^{\mathrm{a}}$ & $\mathbf{1 7 . 8 9} \pm 1.66^{\mathrm{b}}$ & $21.67 \pm 1.90^{\mathrm{a}}$ \\
\hline $\mathrm{C} 18: 2 \omega-6$ & $2.66 \pm 0.06^{\mathrm{a}}$ & $4.27 \pm 0.44^{\mathrm{b}}$ & $1.49 \pm 0.98^{\mathrm{c}}$ & $5.86 \pm 0.11^{\mathrm{d}}$ \\
\hline $\mathrm{C} 18: 3 \omega-3$ & $0.43 \pm 0.15^{\mathrm{a}}$ & $0.73 \pm 0.05^{\mathrm{b}}$ & $0.24 \pm 0.02^{\mathrm{c}}$ & $1.48 \pm 0.45^{\mathrm{d}}$ \\
\hline $\mathrm{C} 20: 2 \omega-6$ & $0.37 \pm 0.06^{\mathrm{a}}$ & $0.42 \pm 0.04^{\mathrm{a}}$ & - & $0.52 \pm 0.08^{\mathrm{b}}$ \\
\hline $\mathrm{C} 20: 3 \omega-6$ & $0.63 \pm 0.01^{\mathrm{a}}$ & $2.77 \pm 0.50^{\mathrm{b}}$ & $0.86 \pm 0.34^{\mathrm{c}}$ & $1.36 \pm 0.98^{\mathrm{d}}$ \\
\hline C20:4 $\omega-6$ & $9.89 \pm 0.18^{\mathrm{a}}$ & $7.76 \pm 0.43^{\mathrm{a}}$ & $13.84 \pm 0.52^{\mathrm{b}}$ & $12.73 \pm 0.49^{b}$ \\
\hline $\mathrm{C} 20: 5 \omega-3$ & $2.14 \pm 0.45^{\mathrm{a}}$ & $1.54 \pm 0.44^{\mathrm{b}}$ & $2.10 \pm 0.08^{\mathrm{a}}$ & $2.42 \pm 0.22^{\mathrm{a}}$ \\
\hline $\mathrm{C} 22: 5 \omega-3$ & $3.69 \pm 0.40^{\mathrm{a}}$ & $1.95 \pm 0.49^{\mathrm{b}}$ & $5.61 \pm 0.33^{\mathrm{c}}$ & $5.73 \pm 0.32^{\mathrm{c}}$ \\
\hline $\mathrm{C} 22: 6 \omega-3$ & $11.60 \pm 0.88^{\mathrm{a}}$ & $5.78 \pm 0.48^{\mathrm{b}}$ & $11.43 \pm 0.09^{\mathrm{a}}$ & $11.92 \pm 0.96^{\mathrm{a}}$ \\
\hline EPUFA $^{* * *}$ & $31.41 \pm 1.44^{\mathrm{a}}$ & $25.22 \pm 1.20^{\mathrm{b}}$ & $35.57 \pm 1.67^{\mathrm{a}}$ & $\mathbf{4 2 . 0 2} \pm 1.55^{\mathrm{c}}$ \\
\hline$\sum \omega-3$ & 17.86 & 10.0 & 19.38 & 21.55 \\
\hline$\sum \omega-6$ & 13.55 & 15.22 & 16.19 & 20.47 \\
\hline$\omega-3 / \omega-6$ & 1.32 & 0.65 & 1.19 & 1.05 \\
\hline
\end{tabular}

* Means are the average of 3 replicates.

** Values are provided as mean \pm S.D. Significant difference at a level of $P<0.05$ is designated by 'a', 'b', 'c', and 'd' (Tukey's test); the same letters in different periods indicate no significant difference.

*** SFA: saturated fatty acids, MUFA: monounsaturated fatty acids, PUFA: polyunsaturated fatty acids. 
and trienoic FAs were also found. In addition, medicinally important PUFAs like C20:5 $\omega-3$ and C22:6 $\omega-3$ were also identifed.

In PL, saturates showed a slight increase with temperature. The maximum SFA contents of PLs in M. mastacembelus were found in the summer (during the spawning season, $50.52 \%$ ), and the lowest in the winter $(36.21 \%)$ (Table 3). SFA showed a significant difference regarding the season $(\mathrm{p}<0.05)$.

The major FA among the SFA group was C16:0 (27.36-36.19\%). The highest concentrations of SFA were C16:0 in July (during the spawning season, $36.19 \%$ ), and C18:0 in September (after spawning season, $10.17 \%$ ). The level of C18:0 was notably lower in January than in September.

The MUFA content of female $M$. mastacembelus showed higher levels in July $(24.11 \%)$ compared to the other seasons. Of these, C18:1 $\omega-9$ was the main MUFA, ranging from $15.42 \%$ to $20.9 \%$ in all seasons, and being observed at the highest value in July. C16:1 $\omega-7$ was the FA present at the second highest level (2.34-3.01\%).

The total PUFA content of PL showed high levels in the winter $(42.02 \%)$ compared to the other seasons. This content indicated lower levels in July (during the spawning season). The main FAs of $\omega-3$ PUFA in M. mastacembelus were DHA and C22:5 $\omega-3$. The DHA content of female fish in the summer (in July, 5.78\%) was lower than in the other seasons, while EPA (1.54-2.42\%) did not show a significant difference with season $(p<0.05)$. DHA increased the PUFA content. Statistically, the AA percentages of PL taken from the M. Mastacembelus varied from $7.76 \%$ (in July) to $13.84 \%$ (in September). C18:2 $\omega-6$ percentages in July and January were high in PUFA. Compared to the total $\omega-6$ PUFA of $20.47 \%$ (with the exception of July) the amount of $\omega$-3 PUFAs was higher and accounted for $21.55 \%$ of the PL of M. mastacembelus in all seasons. The rate of $\omega-3$ to $\omega-6$ PUFA decreased considerably in the reproduction period (in July). $\omega-3 / \omega-6$ ratios of PL fractions were found to be 0.65 (July, during the spawning season)-1.32 (May, before the spawning season).

\subsection{Fatty acid profile of total lipids}

A detailed FA profile of the sum of the lipids and the ratios of $\omega-3$ to $\omega-6$ is presented in Table 4, which is based on the GC chromatogram obtained from the GC analysis.

The highest $\Sigma$ SFA amounts were found in September after the reproduction period $(44.77 \%)$, and the lowest $\Sigma$ SFA were found in July (33.56\%, during the spawning season). In the case of SFA, C16:0 represented the most abundant FA in M. mastacembelus. C18:0, although in a much lesser proportion than $\mathrm{C} 16: 0$, made another important contribution to the SFA. The highest C18:0 percentage was found in September (after the spawning season). Odd carbon chain FAs C13:0, C15:0 and C17:0 were also present in small quantities.

The rate of MUFA in the FA compound was reduced to a minimum level in September (after the spawning season, 21.64\%). C18:1 $\omega-9$ represented the most ample individual MUFA in M. mastacembelus. C18:1 $\omega-9$ in the muscle tissue of M. masatcembelus was found to be $16.38 \%, 24.39 \%$, $24.70 \%$, and $26.60 \%$ in September, May, January, and July, respectively. In September, the concentration of C16:1 $\omega-7$ decreased to its lowest value (4.91\%), while this acid did not present a considerable variation from other months (8.61-10.07\%).

The seasonal variation of the PUFAs in the female muscles ranged from $23.71 \%$ to $32.99 \%$. The proportions of PUFA, $\omega-3$ and $\omega-6$ FAs was reduced to a minimum just before the spawning season in May, and rose after that. AA, C22:5 $\omega-3, \mathrm{C} 18: 2$ $\omega-6$ and DHA were the dominant PUFAs. The levels of EPA varied between $1.53 \%$ (in May) and $2.03 \%$ (in September) and that of DHA, between $7.44 \%$ (in January) and $10.91 \%$ (in July). In the current study, the AA percentages rose in the autumn (after the spawning season, $11.46 \%$ ), while the EPA was reduced before spawning season (in May). In January, the concentration of this acid was reduced to its lowest value $(7.44 \%)$. The DHA amounts were higher than EPA amounts in all seasons. The $\omega-3 /$ $\omega-6$ ratio varied between 1.34 and 2.23 in the muscle tissue of M. mastacembelus.

\section{DISCUSSION}

\subsection{Fat analysis}

The lipid and FA compositions of fish can differ depending on seasonal changes, along with food, age, sex and spawning period (Christiansen et al., 1989). The latest studies have reported that lipid composition was affected by seasonal variations (Kayhan et al., 2015; Kaçar et al., 2016). In the same fish species, the total lipid contents of the gonad and liver changed from 1.32 to $4.90 \%$ and from 1.32 to $3.94 \%$, respectively (Kaçar and Başhan, 2016).

Lipid contents change during the reproduction and nutrition periods in fish. In the reproduction period, the lipids are set in motion from the liver and muscles to the gonads for the improvement of gonads (Castell et al., 1972). This study determined that the amount of total lipids in fish decreased during the reproduction season (in July) and that the amount reached its maximum level during the nutrition season (in May). The reduction of lipid contents in the spawning period with the increase in the reproduction function verified the opinion that the stored lipids were consumed (Vlaming et al., 1978) and the nutrition period was in spring. Therefore, there were 
TABLE 4. Seasonal variations in the fatty acid composition in total lipids of female M. mastacembelus ( $\%$ of total FA)*

\begin{tabular}{|c|c|c|c|c|}
\hline Fatty Acids & May (2008) & July (2008) & September (2008) & January (2009) \\
\hline $\mathrm{C} 10: 0$ & $0.09 \pm 0.01$ & - & - & - \\
\hline C12:0 & $0.11 \pm 0.02$ & - & - & - \\
\hline C13:0 & $0.52 \pm 0.13^{\mathrm{a}}$ & $0.31 \pm 0.10^{\mathrm{b}}$ & $1.20 \pm 0.22^{\mathrm{c}}$ & - \\
\hline C14:0 & $3.77 \pm 0.55^{\mathrm{a}}$ & $3.70 \pm 0.02^{\mathrm{a}}$ & $2.07 \pm 0.37^{\mathrm{b}}$ & $2.15 \pm 0.56^{\mathrm{b}}$ \\
\hline C15:0 & $1.04 \pm 0.03^{\mathrm{a}}$ & $0.61 \pm 0.32^{\mathrm{b}}$ & $0.93 \pm 0.04^{\mathrm{a}}$ & $0.77 \pm 0.01^{\mathrm{b}}$ \\
\hline $\mathrm{C} 16: 0$ & $29.24 \pm 1.22^{\mathrm{a}}$ & $23.52 \pm 1.98^{\mathrm{b}}$ & $30.84 \pm 1.80^{\mathrm{a}}$ & $26.29 \pm 2.76^{\mathrm{b}}$ \\
\hline $\mathrm{C} 17: 0$ & $0.58 \pm 0.03^{\mathrm{a}}$ & $0.56 \pm 0.24^{\mathrm{a}}$ & $0.39 \pm 0.03^{\mathrm{b}}$ & $1.44 \pm 0.07^{\mathrm{c}}$ \\
\hline C18:0 & $5.57 \pm 0.34^{\mathrm{a}}$ & $4.86 \pm 0.46^{\mathrm{a}}$ & $9.34 \pm 0.56^{\mathrm{b}}$ & $4.25 \pm 0.02^{\mathrm{a}}$ \\
\hline $\operatorname{ESFA}^{* * *}$ & $40.92 \pm 2.77^{\mathrm{a}}$ & $33.56 \pm 2.39^{b}$ & $44.77 \pm 1.09^{\mathrm{a}}$ & $34.90 \pm 1.25^{\mathrm{b}}$ \\
\hline C16:1 $\omega-7$ & $9.73 \pm 0.87^{\mathrm{a}}$ & $8.61 \pm 0.56^{\mathrm{a}}$ & $4.91 \pm 0.48^{\mathrm{b}}$ & $10.07 \pm 0.67^{\mathrm{a}}$ \\
\hline C18:1 $\omega-9$ & $24.39 \pm 1.28^{\mathrm{a}}$ & $26.6 \pm 1.07^{\mathrm{a}}$ & $16.38 \pm 1.34^{\mathrm{b}}$ & $24.7 \pm 1.45^{\mathrm{a}}$ \\
\hline $\mathrm{C} 20: 1 \omega-9$ & $0.86 \pm 0.06^{\mathrm{a}}$ & $1.35 \pm 0.04^{\mathrm{b}}$ & $0.35 \pm 0.11^{\mathrm{c}}$ & $0.80 \pm 0.05^{\mathrm{a}}$ \\
\hline IMUFA $^{* * *}$ & $34.98 \pm 1.20^{\mathrm{a}}$ & $36.56 \pm 1.88^{\mathrm{a}}$ & $21.64 \pm 1.34^{\mathrm{b}}$ & $35.57 \pm 1.65^{\mathrm{a}}$ \\
\hline $\mathrm{C} 18: 2 \omega-6$ & $3.57 \pm 0.04^{\mathrm{a}}$ & $3.68 \pm 0.45^{\mathrm{a}}$ & $1.80 \pm 0.56^{\mathrm{b}}$ & $5.56 \pm 0.23^{\mathrm{c}}$ \\
\hline $\mathrm{C} 18: 3 \omega-3$ & $1.14 \pm 0.03^{\mathrm{a}}$ & $1.46 \pm 0.44^{\mathrm{b}}$ & $0.41 \pm 0.06^{\mathrm{c}}$ & $3.45 \pm 0.49^{\mathrm{d}}$ \\
\hline $\mathrm{C} 20: 2 \omega-6$ & $0.35 \pm 0.04^{\mathrm{a}}$ & $0.43 \pm 0.01^{\mathrm{b}}$ & - & $0.58 \pm 0.06^{\mathrm{c}}$ \\
\hline $\mathrm{C} 20: 3 \omega-6$ & $0.45 \pm 0.10^{\mathrm{a}}$ & $0.51 \pm 0.23^{\mathrm{a}}$ & $0.80 \pm 0.09^{\mathrm{b}}$ & $0.83 \pm 0.01^{\mathrm{b}}$ \\
\hline $\mathrm{C} 20: 4 \omega-6$ & $4.47 \pm 0.33^{\mathrm{a}}$ & $4.57 \pm 0.44^{\mathrm{a}}$ & $11.46 \pm 0.98^{\mathrm{b}}$ & $5.59 \pm 0.45^{\mathrm{c}}$ \\
\hline $\mathrm{C} 20: 5 \omega-3$ & $1.53 \pm 0.56^{\mathrm{a}}$ & $1.56 \pm 0.66^{\mathrm{a}}$ & $2.03 \pm 0.40^{\mathrm{b}}$ & $1.58 \pm 0.10^{\mathrm{a}}$ \\
\hline $\mathrm{C} 22: 5 \omega-3$ & $3.79 \pm 0.11^{\mathrm{a}}$ & $6.63 \pm 0.50^{\mathrm{b}}$ & $6.04 \pm 0.65^{\mathrm{b}}$ & $4.43 \pm 0.67^{\mathrm{a}}$ \\
\hline $\mathrm{C} 22: 6 \omega-3$ & $8.41 \pm 0.48^{\mathrm{a}}$ & $10.91 \pm 0.90^{\mathrm{a}}$ & $10.45 \pm 0.65^{\mathrm{a}}$ & $7.44 \pm 0.56^{\mathrm{a}}$ \\
\hline EPUFA ${ }^{* * *}$ & $23.71 \pm 1.26^{\mathrm{a}}$ & $29.75 \pm 1.89^{b}$ & $32.99 \pm 1.09^{\mathrm{b}}$ & $29.46 \pm 1.56^{\mathrm{b}}$ \\
\hline$\Sigma \omega-3$ & 14.87 & 20.56 & 18.93 & 16.9 \\
\hline$\Sigma \omega-6$ & 8.84 & 9.19 & 14.06 & 12.56 \\
\hline$\omega-3 / \omega-6$ & 1.68 & 2.23 & 1.34 & 1.34 \\
\hline
\end{tabular}

* Means are the average of 3 replicates.

** Values are provided as mean \pm S.D. Significant difference at a level of $P<0.05$ is designated by 'a', 'b', 'c', and 'd' (Tukey's test); the same letters in different periods indicate no significant difference.

*** SFA: saturated fatty acids, MUFA: monounsaturated fatty acids, PUFA: polyunsaturated fatty acids.

significant differences due to seasonal factors influencing total muscle lipid contents.

\subsection{Fatty acid profile of total lipids}

Our findings are also in close agreement with those reported by Haliloğlu et al., (2004), Akpinar et al., (2009) and Cengiz et al., (2012) for other freshwater fish.

In our research, the SFAs were detected to be in higher quantities than in the MUFAs and PUFAs in May and September. However, in another study on M. mastacembelus, it was found that total PUFA were the highest $(37.1 \%)$ in the Keban Dam Lake, and that this was followed by MUFA (35.5\%) and SFA (27.4\%) (Harlığlu and Yllmaz, 2010). C16:0 was the primary SFA. Similar results for M. mastacembelus in the Atatürk Dam Lake (Olgunoğlu, 2011; Taşbozan et al., 2013) have also been reported in the literature. $\mathrm{C} 18: 1 \omega-9$ was determined as the main MUFA in M. mastacembelus for all seasons. In the present study, C18:1 $\omega-9$ remained relatively stable in all seasons (with the exception of September, 16.38\%). Olgunoğlu (2011) and Taşbozan et al., (2013) found the same results for M. Mastacembelus caught from the Atatürk Dam Lake.

In the present study, the majority of PUFAs in fish oils ranged from $\mathrm{C} 18$ to $\mathrm{C} 22$ in chain length and were of the $\omega$-3 type. In September, a high ratio of AA raised the $\omega-6$ PUFA content. $M$. mastacembelus muscle was rich in DHA. This finding agrees with results from M. mastacembelus in the Atatürk Dam Lake (Olgunoğlu 2011; Taşbozan et al., 2013). DHA is more abundant in fish from cold region (Ackman, 1967). However, in this study, M. mastacembelus demonstrated a low grade of total $\omega-6$ PUFA, but a high grade of total $\omega-3$ PUFA.

C18:2 $\omega-6$ and AA were the predominant $\omega-6$ PUFA. This is confirmed by the results of Luczyńska et al., (2008) and Ugoala et al., (2008). 
It may be seen that the DHA was the main PUFA in the female M. mastacembelus muscle tissue and had the maximum percentage in July (during the spawning season, $10.91 \%$ ).

In the current research, it was determined that PUFA and the $\omega-3$ FA level were reduced in the spring (before the reproduction period). A high level of $\omega-6$ PUFA lowered the $\omega-3 / \omega-6$ ratio in September and January.

The monitored decrease in PUFA and $\omega-3$ FA is possibly due to their use for reproduction. The low proportion of $\omega-3 / \omega-6$ PUFA increases the pathogens of numerous diseases such as cardiovascular diseases and inflammations. Enzyme activity and chain prolongation which enable de-saturation reduces $\omega-3$ PUFAs and increases $\omega-6$ PUFAs in freshwater fish. This is the reason behind the low proportion of $\omega-3 / \omega-6$ in freshwater fish. The amount of this ratio ranged from 1.34 to 2.23 . It has been thought that a rate of $1 / 1$ to $1 / 5$ would contribute to a healthy human diet.

\subsection{Fatty acid profile of PL fraction}

In the PL fraction, C16:0 was the predominant SFA in all seasons in the present study. This FA has been notified in many studies as the primary SFA in freshwater fish (Akpınar et al., 2009; Aras et al., 2003). The reasons for high C16:0 rates of PLs in May, July and September could be related to water temperature and reproduction activity. In the muscles of the female, the rate of SFA in the FA composition increased to a maximum grade in July (the reproduction period). In this term, water temperature considerably increases.

C18:1 $\omega-9$ was the most ample of the monoenes in all seasons. Our findings concerning the C18:1 $\omega-9$ FA are almost comparable to the concentration reported by Haliloğlu et al., (2004) and Cengiz et al., (2012) for the same FA in the muscle of freshwater fish. A low level of C16:1 $\omega-7$ lowered the MUFA contents of M. mastacembelus.

AA was high in all seasons in the PL fractions. $\mathrm{AA}$ is a primer for prostaglandin and thromboxane, which affect blood clot formation and its adherence to the endothelial tissue during wound healing (Sargent et al., 2002). Furthermore, AA shows a significant role in growth. The high grade of PUFA, particularly C20:4 $\omega-6$, is most likely seen in fish as a consequence of lower oxygen solubility in warmer waters.

DHA is a main constituent of the brain, the retina, and heart muscles and plays an important role in brain and eye development (Ward and Singh, 2005). In this study, DHA was high in all seasons except for the summer season. PUFAs, like DHA, would seem to be good candidates for providing steady fluidity at the related body temperature because of their low melting points. Reduction in DHA concentrations in lipids would accordingly be expected in warmer waters like the Ataturk Dam Lake.

The melting temperatures of EPA are lower than those of AA. Therefore, the EPA contents of fish in cold regions are higher than those of fish in warm regions (Çelik et al., 2005).

The total PUFA level decreased in the spawning period (in July). This indicates that the PUFAs could be used in the reproduction period. The reason is that FAs are not only the main source of metabolic energy in fish for growth, but they are also the main source of metabolic energy for reproduction (Tocher, 2003). The highest total PUFA quantities of PLs were detected in the winter (in January). Total PLs from fish muscle tissues are characteristically rich in PUFA (Bayır et al., 2010; Gunstone et al., 1978); however, in our research, the most ample fraction of PLs was SFA (with the exception of January), not PUFA, because of the high 16:0 ratio in SFA.

\subsection{Fatty acid profile of TAG fraction}

In the TAG fraction, C16:0 was the major SFA in all months. In this research, no significant difference could be determined in total SFA with respect to reproduction period or season.

C16:1 $\omega-7$ and C18:1 $\omega-9$ predominated over the MUFA fraction in M. mastacembelus, and this is similar to other freshwater fish from other sites (Ackman, 1967; Osman et al., 2001). Since diet is the major factor affecting tissue FA composition in fish, high MUFA rates in May (before the spawning season) and July (during the spawning season) are probably related to increased feeding activity. C18:1 $\omega-9$ was accumulated in TAG, which is consistent with its potential role as a source of metabolic energy.

C18:2 $\omega-6$ is a major FA in total and TAGs of fish (Almeida and Franco, 2007). In September, a low level of C18:2 $\omega-6$ reduced the PUFA content in this fish.

In winter, low levels of DHA and EPA reduced the PUFA content. The reason for the results found is probably the feeding habits of the fish. The percentages of PUFA like EPA and DHA in fish muscle are related to diet (Arts et al., 2001).

In other studies, it was found that the $\omega-3 / \omega-6$ rates of PLs were generally higher than TAGs (Kayhan et al., 2015; Cengizet al., 2012). However, in this study, the $\omega-3 / \omega-6$ rates of PLs $(0.65-1.32)$ were lower compared to those of TAGs (0.81-3.48).

According to Wills and Hopkirk (1976), the MUFA levels were the highest group and PUFAs were the lowest group in the TAG fraction, which can be a possible consequence of the accumulation of depot lipids in the form of MUFA and SFAs. This conforms with other studies where it has been indicated that monoenes are used as the preferred 
substrate for catabolism (Henderson and Tocher, 1987). Total PLs from fish muscle tissue is typically rich in PUFA (Gunstone et al., 1978); however, in this research, the most ample fraction of PLs was SFA, not PUFA, because of the high 16:0 ratio in SFA (except in winter). This may be due to the high water temperature of the dam lake.

Henderson and Tocher (1987) reported that fish TAGs include high levels of C18:1 $\omega-9$ and C16:1 $\omega-7$. In this study, in TAG fraction MUFAs were higher than the PL fraction in all seasons.

The lipid fractions showed that the PL were formed of very high levels of PUFA, particularly DHA and AA, and their composition appeared to be better regulated than the composition of TAG. The results also indicate that DHA may have been transferred from TAG to PL.

\section{CONCLUSION}

$\omega$-3 PUFA was dominated by the DHA of FA composition of total lipids, PL and TAG. The dominant $\omega-6$ is of the AA in the PL fractions in all seasons. The total lipid contents varied seasonally from $0.50 \%$ to $3.59 \%$. These results indicate that the FA profiles were different according to season and that the $M$. mastacembelus is a potential dietary source of FAs from the nutritional standpoint.

\section{ACKNOWLEDGEMENTS}

This research was financially supported by the Scientific Research Project of Dicle University

(DUAPK-08-FF-07).

\section{REFERENCES}

Ackman RG. 1967. Characteristics of the FA composition and biochemistry of some freshwater fish oils and lipids in composition with marine oils and lipids. Comp. Biochem. Physiol. 22, 907. https://doi.org/10.1016/0010-406X(67)90781-5

Akpinar MA, Görgün S, Akpinar AE.2009. A comparative analysis of the fatty acid profiles in the liver and muscles of male and female Salmo trutta macrostigma. Food Chem. 112, 6-8. https://doi.org/10.1016/j.foodchem.2008.05.025

Almeida NM, Franco MRB. 2007. Fatty acid composition of total lipids, neutral lipids and phospholipids in wild and farmed matrinxa (Brycon caphalus) in the Brazilian Amazon area. J. Sci. Food Agric. 87, 2596-2603. https:// doi.org/10.1002/jsfa.3014

Aras NM, Haliloğlu Hİ, Bayır A, Atamanalp M, Sirkecioğlu AN. 2003. Karasu Havzası Yeşildere Çayı olgun dere alabalıkları (Salmo trutta macrostigma, Dumeril, 1858)'nda farklı dokuların yă asidi kompozisyonlarının karşılaștırılması. Turk. J. Vet. Anim. Sci. 27, 887-892.

Arts MT, Ackman RG, Holub BJ. 2001. Essential fatty acids in aquatic ecosystems: a crucial link between diet and human health and evolution. Can. J. Fish Aquat. Sci. 58, 122-137. https://doi.org/10.1139/f00-224

Bayır A, Sirkecioglu AN, Aras NM, Aksakal E, Haliloglu HI, Bayir M. 2010. Fatty acids of neutral and phospholipids of three endangered trout: Salmo trutta caspius Kessler, Salmo trutta labrax Pallas and Salmo trutta macrostigma Dumeril. Food Chem. 119, 1050-1056. https://doi. org/10.1016/j.foodchem.2009.07.064
Castell JD, Sinnhuber RO, Wales JH, Lee DJ. 1972. Essential fatty acids in the diet of rainbow trout (Salmo gairdnerii): Growth, feed conversion and some gross deficiency symptoms. J. Nutr. 102, 77-86.

Cengiz EI, Ünlü E, Bashan M, Satar A, Uysal E. 2012. Effects of seasonal variations on the fatty acid composition of total lipid, phospholipid and triacylglicerol in the dorsal muscle of Mesopotamian Catfish (Silurus triostegus Heckel, 1843) in Tigris River (Turkey). Turk. J. Fish. Aquat. Sci. 12, 33-39. https://doi.org/10.4194/1303-2712-v12_1_05

Christiansen JS, Ringo E, Farkas T. 1989. Effect of sustained exercise on growth and body composition of first feeding fry of Arctic charr, Salvelinus alpinus (L.). Aquaculture 79 , 329-335. https://doi.org/10.1016/0044-8486(89)90474-2

Çelik M, Diler A, Küçükgülmez A. 2005. A comparison of the proximate compositions and fatty acid profiles of zander (Sander lucioperca) from two different regions and climatic conditions. Food Chem. 92, 637-641. https://doi. org/10.1016/j.foodchem.2004.08.026

Folch J, Lees M, Stanley A. 1957. Simple method for the isolation and purification of total lipids from animal tissues. J. Biol. Chem. 226, 497-509.

Gunstone FD, Wijesundera RC, Scrimgeour CM. 1978. The component acids of lipids from marine and freshwater species with special reference to furan-containing acids. J. Sci. Food Agric. 29, 539-550. https://doi.org/10.1002/ jsfa. 2740290608

Haliloğlu HI, Bayır A, Sirkecioğlu N, Aras NM, Atamanalp M. 2004. Comparison of fatty acid composition in some tissue of rainbow trout (Oncorhynchus mykiss) living in seawater and freshwater. Food Chem. 86, 55-59. https://doi. org/10.1016/j.foodchem.2003.08.028

Harlıŏlu AG, Yilmaz Ö. 2010. Fatty acid composition, cholesterol and fat soluble vitamins of wild-caugth freshwater speeny eel, Mastasembelus simack (Walbaum, 1792). J. Appl. Ichthyol. 27, 1123-1127. https://doi.org/10.1111 j.1439-0426.2011.01750.x

Henderson RJ, Tocher DR. 1987. The lipid composition and biochemistry of freshwater fish. Prog. Lipid Res. 26, 281-347. https://doi.org/10.1016/0163-7827(87)90002-6

Kaçar S, Başhan M. 2015. Seasonal Variations in the Fatty Acid Composition of Phospholipid and Triacylglycerol in Gonad and Liver of Mastacembelus simack. J. Am. Oil Chem. Soc. 92, 1313-1320. https://doi.org/10.1007/ s11746-015-2692-6

Kaçar S, Başhan M, Oymak AS. 2016. Effect of seasonal variation on lipid and fatty acid profile in muscle tissue of male and female Silurus triostegus. J. Food Sci. Technol. Mys. 53, 2913-2922. https://doi.org/10.1007/ s13197-016-2253-5

Kayhan H, Başhan M, Kaçar S. 2015. Seasonal variations in the fatty acid composition of phospholipids and triacylglycerols of brown trout. Eur. J. Lipid Sci. Technol. 117, 738-744. https://doi.org/10.1002/ejlt.201400152

Łuczyńska J, Borejszo Z, Łuczyński MJ. 2008. The composition of fatty acids in muscles of six freshwater fish species from the Mazurian Great Lakes (northeastern Poland). Arch. Pol. Fish. 16, 167-178. https://doi.org/10.2478/ s10086-008-0014-4

Olgunoğlu IA. 2011. Determination of the fundamental nutritional components in fresh and hot smoked spiny eel (Mastacembelus mastacembelus, Bank and Solander, 1794). Sci. Res. Essays. 6, 6448-6453.

Osman H, Suriah AR, Law EC.2001. Fatty acid composition and cholesterol content of selected marine fish in Malaysian waters. Food Chem.73, 55-60. https://doi.org/10.1016/ S0308-8146(00)00277-6

Sargent JR, Tocher DR, Bell JG. 2002. The lipids. In: Halver J.E., Hardy R.W. (eds): Fish Nutrition. 3rd Ed. Elsevier Science, San Diego: 181-257.

Shirai N, Suzuki H, Tokairin S, Eharac H, Wada S.2002. Dietary and seasonal effects on the dorsal meat lipid composition of Japanese (Silurus asotus) and Thai catfish (Clarias macrocephalus and hybrid Clarias macrocephalus and Clarias galipinus). Comp. Biochem. Physiol. 132, 609-619. https:// doi.org/10.1016/S1095-6433(02)00081-8 
Sidhu KS. 2003. Health benefits and potential risks related to consumption of fish or fish oil. Regul. Toxicol. Pharmacol. 38, 336-344. https://doi.org/10.1016/j.yrtph.2003.07.002

Taşbozan O, Gökçe MA, Çelik M, Tabakoğlu ŞS, Küçükgülmez A, Başusta A.2013. Nutritional composition of Spiny eel (Mastacembelus mastacembelus) caught from the Atatürk Dam Lake in Turkey. J. Appl. Biol. Sci. 7,78-82.

Tocher DR. 2003. Metabolism and functions of lipids and fatty acids in teleost fish. Fish. Sci. 11, 107-184. https://doi. org/10.1080/713610925

Ugoala Ch, Ndukwe GI, Audu TO.2008. Comparison of fatty acids of some freshwater and marine fishes. Int. J. Food Saf. 10, 9-17.
Vlaming VLD, Kuris A, Parker FR. 1978. Seasonal variations of reproduction and lipid reserves in some subtropical cyprinodantids. Trans. Am. Fish. Soc. 107, 464-472. https://doi.org/10.1577/1548-8659(1978)107<464:SVOR $\mathrm{AL}>2.0 . \mathrm{CO} ; 2$

Ward OP, Singh A. 2005. Omega-3/6 fatty acids: alternative sources of production. Process. Biochem. 40, 3627-3652. https://doi.org/10.1016/j.procbio.2005.02.020

Wills RBH, Hopkirk G.1976. Distribution and fatty acid composition of lipids of Eels (Anguilla australis). Comp. Biochem. Physiol. 53B, 525-527. https://doi. org/10.1016/0305-0491(76)90211-X 